\title{
Akibat Setitik Kejahatan, Rusak Kebaikan Sebelanga
}

\author{
Subhan El Hafiz \\ Fakultas Psikologi \\ Universitas Muhammadiyah, Prof. Dr. HAMKA, \\ J1.Limau II, Kebayoran Baru, Jakarta Selatan \\ subhanhafiz@gmail.com
}

\begin{abstract}
Purpose of this research was to assess how ones make moral judgment in moral dilemma situation if both aspect, receive and reject, were equal. This research was conduct by two studies and the purpose of first study is to identify evil and good behavior with their own reason. Meanwhile the purpose of second study was to evaluate how ones judge dilemma that create from first study, which are made of good action with evil reason and evil action with good reason. Method used in first study was survey to 32 research participants and method for second study was experiment to 53 participants. The first study was resulting eight evil behavior and six good behaviors that most mentioned by participants with 12 most common reason on each group. Result for second study was ones judge situations of dilemma moral as evil. These results showed that good cannot be combined with evil in one dilemma and it will be judged as evil whatever the order. Based on these findings, ones moral will judge dilemma as evil if both side, good and evil, in equal position.
\end{abstract}

Key words: moral; moral judgment; moral dilemma; good; evil.

\begin{abstract}
Abstrak-Penelitian ini bertujuan untuk melihat bagaimana individu melakukan penilaian moral pada situasi dilema jika bobot dari aspek yang diterima dan ditolak seimbang. Penelitian ini dilakukan melalui dua studi, Tujuan dari studi pertama adalah untuk mengidentifikasi perilaku jahat dan perilaku baik beserta alasannya, sedangkan studi kedua bertujuan untuk melihat penilaian moral pada dilema jika hasil studi pertama disilang, yaitu perilaku baik dengan alasan jahat dan perilaku jahat dengan alasan baik. Metode yang digunakan pada studi pertama adalah survei kepada 32 partisipan dan studi kedua adalah eksperimen kepada 53 partisipan yang berbeda. Hasil studi pertama menghasilkan delapan perilaku jahat dan enam perilaku baik yang paling banyak disebut bersama 12 alasan paling umum dari masing-masing kelompok tindakan. Pada studi kedua, hasil penelitian menunjukkan bahwa dilema yang dibentuk dari perilaku dan alasan yang bertolak belakang akan dinilai jahat oleh individu. Hasil ini menunjukkan bahwa kebaikan yang disatukan dengan kejahatan
\end{abstract}


dalam sebuah dilema akan tetap dinilai jahat bagaimanapun urutannya. Berdasarkan penelitian ini, sebuah penilaian moral akan menilai dilema sebagai jahat jika bobot antara dua kutub seimbang.

Kata kunci: moral; penilaian moral; dilema moral; kebaikan; kejahatan.

\section{PENDAHULUAN}

Moral merupakan salah satu konsep yang paling diharapkan dalam upaya menyelesaikan masalah sosial saat ini. Untuk itu, optimalisasi peran moral merupakan salah satu hal yang penting sebagai upaya mengatasi masalah sosial yang banyak dihadapi oleh manusia. Korupsi, pencurian, kekerasan, dan sebagainya diharapkan dapat dihadapi dengan memperkuat nilai moral pada diri individu yang kemudian dapat mencegah perilaku yang tidak sesuai dengan nilai moral.

Penelitian terkait moral dan perilaku individu menunjukkan bahwa moral dapat mencegah seseorang melakukan perilaku yang tidak sesuai dengan konsep moralnya selama emosi negatif yang muncul sebelum perilaku cukup kuat untuk mencegah perilaku tersebut (Haidth dan Kesebir, 2010, El Hafiz, 2003, Helmuth, 2001). Emosi ini juga yang oleh Hare (1993) dijadikan indikator kesehatan mental individu dalam berperilaku sesuai dengan konsep moral seseorang. Dalam penelitiannya, Hare menunjukkan bahwa orang-orang yang tidak sehat mental cenderung tidak sejalan antara: tindakan, emosi, dan pikirannya.

Namun bagaimana seseorang menilai kondisi yang nilai secara moral masih menjadi pertanyaan. Suharsono (2000) mengatakan bahwa penilaian terhadap situasi dikenal dengan konsep appraisal dan hasil dari appraisal akan menjadi acuan apakah lingkungan yang dinilai sesuai atau tidak dengan konsep moralnya. Namun Suharsono tidak menjelaskan secara rinci bagaimana appraisal dapat terjadi, bahkan dalam penjelasannya Suharsono seolah mengatakan bahwa appraisal terjadi secara otomatis.

Fakor lain yang menjadi dasar penilaian seseorang adalah worldview, yaitu pandangan terhadap lingkungan yang banyak dibentuk oleh budaya di mana individu dibesarkan. Namun menurut Miller, konsep yang diajukan oleh Jensen ini masih banyak celah yang harus terus digali dan diperbaiki untuk memperkuat kosepnya. Konsep worldview yang diajukan Jensen ini lebih banyak menekankan pada interaksi antara kepribadian dan kebudayaan (Miller, 1997; Dien, 1997).

Penelitian-penelitian lain terkait dengan penilaian moral (moral judgment) juga tidak cukup spesifik membahas bagaimana proses seseorang membuat penilaian terhadap kondisi yang dihadapi. Burns (2008) mengatakan bahwa penilaian moral dapat dijelaskan dengan mengikuti dasar-dasar logika, misalnya: jika A bagian dari B, B dinilai baik maka A pun akan dinilai baik. Selain itu Burns juga mengatakan bahwa penilaian moral baru akan terjadi apabila telah terpenuhi beberapa syarat yang berhubungan dengan hal itu, antara lain: individu sadar bahwa dirinya harus memilih, individu sadar bahwa terdapat alternatif pilihan, dan individu memiliki pengetahuan terhadap pilihan yang ada.

Konsep lain mengenai penilaian moral ini disampaikan oleh banyak peneliti lain yang mengatakan bahwa penilaian moral banyak dipengaruhi oleh emosi seseorang. Arah dari emosi seseorang terhadap situasi akan mempengaruhi bagaimana penilaian moral seseorang terhadap situasi tersebut. Konsep emosi yang muncul sebelum penilaian moral menjadi salah satu dasar konsep optimalisasi peran emosi sebagai sistem peringatan dini moral (El Hafiz, 2003).

Nucci (2002) mengajukan argumen yang berbeda dalam pelabelan perilaku baik dan jahat dalam kehidupan sehari-hari. Menurut Nucci, penilaian moral dan perilaku moral seseorang sangat bergantung 
pada pengetahuannya tentang moral dan identitas personal dirinya. Dengan demikian, Nucci mengajukan argumen bahwa penentuan perilaku tertentu, apakah baik atau jahat, selain terkait dengan pengetahuan tentang perilaku tersebut, juga ditentukan bagaimana konsep diri dan identitas diri individu.

Pertanyaannya, bagaimana penilaian moral seseorang jika dirinya menghadapi logika dari dua hal yang saling bertolak belakang dalam satu kejadian, apakah prinsip logika yang diajukan Burns berlaku dalam hal ini? Begitu juga ketika seorang individu tidak terlibat secara emosional dengan masalah yang dihadapi, bagaimana individu akan menilai situasi terhadap nilai moral yang diyakininya? Bagaimana sebenarnya cara kerja penilaian moral dalam menghadapi masalah dalam kehidupan sehari-hari merupakan pertanyaan yang dicoba untuk dijawab dalam penelitian ini.

Pertanyaan yang hampir sama juga diajukan oleh Schwartz (2004) dalam diskusi mengenai perkembangan moral dan penilaian moral. Schwartz mengatakan dengan berkembangnya penelitian tentang moral yang lebih mengarahkan pada konsep moral sebagai reaksi otomatis, maka penggunaan kesadaran dalam mengambil keputusan perlu menjadi aspek-aspek yang dikembangkan dan diteliti. Pertanyaan yang diajukan oleh Schwartz ini sesungguhnya menjadi dasar argumen untuk menghadapi argumen masalah moral yang mengatakan bahwa moral tidak dapat menjadi dasar perilaku manusia.

Kegusaran terhadap penelitian moral juga disampaikan oleh Krause (2009) yang mengatakan bahwa selama ini penelitian moral lebih mengarahkan pada saat individu menghadapi masalah moral dan ketika "agen moral" dalam otak baru mulai diaktifkan. Hal ini menyebabkan penelitian moral lebih banyak membahas masalah bagaimana manusia menentukan pilihan untuk menghadapi masalah moral atau dilemma moral. Namun, menurut Krause, penelitian moral harus dikembangkan hingga menjadi konsep untuk mendorong sikap saling percaya atau untuk membangun kerja sama.

Hal yang sama disampaikan oleh Haidth dan Kesebir (2010) yang mengatakan bahwa sebagian besar penelitian moral justru hanya untuk menyelesaikan dilemma moral. Adapun salah satu dilema moral yang sering menjadi objek penelitian adalah apakah manusia akan memilih membunuh satu orang untuk menyelamatkan lima orang atau membiarkan lima orang terbunuh dan satu orang selamat dengan tidak melakukan apa pun. Menurut Haidth, penelitian ini justru lebih banyak menyebabkan munculnya kebingungan moral yang tidak dapat menyelesaikan problem sosial.

Permasalahan di atas tidak hanya terjadi pada level teoritis namun juga menjadi pertanyaan pada level praksis. Sebagai contoh ketika individu melihat pemukulan yang dilakukan oleh orang tua kepada anak dengan alasan pendisiplinan, apakah individu akan menilai orang tua tersebut jahat atau sebaliknya. Implikasi dari penilaian moral terhadap situasi tersebut adalah keputusan individu untuk membantu atau tidak membantu dalam upaya mencegah atau menghentikan tindakan pemukulan.

Walaupun ada banyak variabel lain yang akan terlibat ketika seseorang memutuskan untuk membantu atau tidak, namun penilaian moral terhadap perilaku menjadi salah satu dasar bagaimana individu akan mengambil keputusan. Dasar pemikiran terhadap hal itu adalah: apabila individu menilai perilaku yang dihadapinya jahat, karena tidak sesuai dengan nilai moral, maka kemungkinan individu mengambil tindakan untuk membantu akan semakin besar. Sebaliknya jika penilai individu terhadap perilaku adalah baik maka individu akan membatasi diri untuk terlibat dan memberikan bantuan. 


\section{STUDI 1}

\section{METODE}

\section{Partisipan}

Partisipan dalam studi pertama adalah 32 orang mahasiswa Jurusan Kesehatan Masyarakat, Fakultas Ilmu Kesehatan, Universitas Muhammadiyah Prof. Dr. HAMKA. Sebaran dari partisipan terdiri dari 8 orang laki-laki dan 24 orang perempuan dan sesuai dengan karakterisik jurusan tersebut yang lebih didominasi perempuan. Usia partisipan penelitian dalam studi ini berkisar antara 17-22 tahun yang tersebar secara merata pada laki-laki dan perempuan.

\section{Desain}

Penelitian ini menggunakan metode survei. Adapun pertanyaan survei terdiri dari empat pertanyaan terbuka, selain identitas pribadi yang dibutuhkan dalam penelitian. Pertanyaan disampaikan secara lisan, kemudian partisipan diminta menjawab pertanyaan tersebut dalam selembar kertas.

\section{Prosedur}

Pengumpulan data dilakukan menggunakan kuisioner yang terdiri dari empat pertayaan terbuka. Pertanyaan tersebut masing-masing terdiri dari dua pertanyaan yang saling berpasangan dan menjadi satu kesatuan. Adapun pertanyaan yang disampaikan adalah: (1) Sebutkan lima perilaku yang anda nilai baik?; (2) Jelaskan mengapa anda menilai perilaku tersebut baik?; (3) Sebutkan lima perilaku yang anda nilai jahat?; (4) Jelaskan mengapa anda menilai perilaku tersebut jahat?;.

\section{Teknik Analisis}

Analisis yang dilakukan dalam studi ini adalah analisis deskriptif dengan membuat gambaran sebaran jawaban partisipan terhadap pertanyaan yang diajukan. Berdasarkan jawaban partisipan terhadap pertanyaan, "Sebutkan lima perilaku baik?" dan "Sebutkan lima perilaku jahat?," peneliti melakukan tabulasi untuk menentukan perilaku jahat yang paling umum dan perilaku baik yang paling umum. Hasil tabulasi dari jawaban responden akan menunjukkan perilaku jahat yang paling umum dan perilaku baik yang paling umum.

Pada lanjutan, yaitu pertanyaan yang meminta partisipan memberikan alasan penilaian baik dan jahat sebuah perilaku, peneliti melakukan analisis isi terhadap alasan yang muncul dari masing-masing perilaku, yang baik dan jahat. Hasil analisis akan menunjukkan alasan-alasan yang dinilai baik dan alasan-alasan yang dinilai jahat, sedangkan alasan yang terlalu abstrak akan diabaikan. Hasil ini juga akan menunjukkan alasan baik yang paling umum dan alasan jahat yang paling umum. 


\section{ANALISIS \& HASIL}

Berdasarkan analisis terhadap data yang dikumpulkan dalam studi pertama ini didapatkan beberapa perilaku yang dikategorikan perilaku baik dan perilaku jahat serta alasan baik dan alasan jahat. Berdasarkan data yang masuk, peneliti melakukan seleksi terhadap jenis perilaku dengan membuat peringkat berdasarkan seberapa sering perilaku jahat atau baik disebut oleh partisipan, kemudian peneliti mengambil perilaku yang disebut minimal enam kali dari keseluruhan perilaku yang disebut atau lebih dari $4 \%$ pada perilaku baik dan lebih dari $3.5 \%$ pada perilaku jahat. Hasilnya didapatkan enam perilaku baik dan delapan perilaku jahat yang disebut minimal enam kali.

Berdasarkan hasil analisis terhadap data yang diperoleh, didapatkan enam perilaku yang dinilai baik yaitu: menolong, sedekah, jujur, sabar, hormat kepada orangtua, dan sopan. Sedangkan perilaku jahat yang disebut lebih dari enam kali adalah: membunuh, korupsi, mencuri, berbohong, berkhianat, memperkosa, memfitnah, dan mengolok-olok. Berdasarkan sejumlah perilaku yang disebutkan di atas, peneliti menarik berbagai alasan yang menjadi alasan baik dan alasan jahat berdasarkan perilaku jahat dan baik yang disebut minimal enam kali.

Tabel 1. Jumlah dan Persentase Perilaku Jahat dan Baik

\begin{tabular}{lcc}
\hline \multicolumn{1}{c}{ Perilaku Jahat } & Jumlah & $\%$ \\
\hline Mencuri & 25 & 15.6 \\
Pembunuhan & 21 & 13.1 \\
Korupsi & 16 & 10 \\
Fitnah & 7 & 4.4 \\
Memperkosa & 7 & 4.4 \\
Berkhianat & 7 & 4.4 \\
Mengolok-olok & 7 & 4.4 \\
Berbohong & 6 & 3.8 \\
\hline Lainnya (35 perilaku) & $(64)$ & 39.9 \\
\hline
\end{tabular}

\begin{tabular}{lcc}
\hline \multicolumn{1}{c}{ Perilaku Baik } & Jumlah & \% \\
\hline Menolong & 21 & 14.5 \\
Sedekah & 16 & 11 \\
Jujur & 14 & 9.7 \\
Sabar & 10 & 6.9 \\
Sopan & 10 & 6.9 \\
Menghormati orangtua & 6 & 4.1 \\
\hline Lainnya (43 perilaku) & $(68)$ & 46.9 \\
\hline
\end{tabular}

Adapun alasan yang disebutkan dalam perilaku tersebut, setelah dikurangi alasan yang terlalu abstrak dan tidak cukup bisa dijadikan alasan, masing-masing ada dua belas. Alasan jahat yang didapat dari hasil analisis terhadap perilaku jahat adalah: melanggar hukum, merugikan orang lain, membuat sedih orang lain, merusak masa depan orang lain, menyakiti orang lain, membodohi manusia, membuat orang cemas, membahayakan orang lain, membuat orang sakit hati, membuat orang kesulitan, merusak hubungan dengan orang lain, dan tanpa sepengetahuan orang lain. Sedangkan alasan baik yang didapat dari studi satu ini adalah menghindari konflik, lebih dihargai, tidak menyakiti perasaan, menciptakan keharmonisan, mengendalikan perilaku, menghindari masalah yang lebih besar, membantu sesama, membuat orang lain senang, mengurangi kesulitan orang lain, sangat dibutuhkan orang lain, menghindari salah paham, dan berakhir baik. 


\section{STUDI 2}

\section{METODE}

\section{Partisipan}

Partisipan dalam studi kedua sebanyak 53 orang mahasiswa yang tersebar pada dua fakultas, yaitu Fakultas Psikologi dan Fakultas Ilmu Kesehatan, Jurusan Kesehatan Masyarakat. Sebaran partisipan terdiri dari 26 mahasiswa Fakultas Psikologi dan 27 orang mahasiswa Fakultas Ilmu Kesehatan. Usia partisipan dalam studi kedua ini berada dalam rentang 17-21 tahun.

Berdasarkan jenis kelamin, partisipan di Fakultas Psikologi terdiri dari 8 orang laki-laki dan 18 orang perempuan, sedangkan pada partisipan di Fakultas Ilmu Kesehatan terdiri dari 11 laki-laki dan 18 orang perempuan. Dengan demikian, sebaran total berdasarkan jenis kelamin adalah 17 orang laki-laki dan 36 orang perempuan. Sebaran tersebut hampir sama dengan sebaran mahasiswa pada fakultas yang menjadi lokasi partisipan yaitu lebih didominasi oleh perempuan.

\section{Desain}

Pada studi, penelitian dilakukan menggunakan metode eksperimen dengan rancangan kelompok acak (random group design). Rancangan ini membagi partisipan secara acak dalam kelompok eksperimen dan kelompok kontrol yang masing-masing mendapat perlakuan yang berbeda. Berdasarkan perbedaan perlakuan tersebut, reaksi partisipan dilihat dan dibedakan berdasakan kelompoknya (Shaughhnessy, Zechmeister, dan Zechmeister, 2007).

\section{Prosedur}

Partisipan penelitian dibagi ke dalam dua kelompok yang diacak berdasarkan susunan, yaitu: kelompok pertama berfungsi sebagai kelompok eksperimen dan kelompok kedua berfungsi sebagai kelompok kontrol. Susunan situasi yang akan diberikan pada responden disusun berdasarkan situasi kontrol dan situasi eksperimen secara bergantian yang kemudian dibagikan pada partisipan tanpa mereka mengetahui situasi yang akan mereka terima. Kelompok pertama diberi sebuah situasi dilema dalam bentuk kalimat untuk direspon oleh partisipan sedangkan kelompok kedua diberi situasi yang tidak menggambarkan dilema.

Adapun situasi dilema adalah situasi yang disusun dari perilaku yang berseberangan dengan alasan, yaitu: perilaku jahat dengan alasan baik serta perilaku baik dengan alasan jahat. Sedangkan situasi dilema merupakan situasi yang disusun dari perilaku dan alasan yang sama dengan situasi dilema namun tidak dalam kondisi bersebrangan, yaitu: perilaku baik dengan alasan baik dan perilaku jahat dengan alasan jahat.

Studi kedua ini, pengumpulan data dilakukan menggunakan angket yang menggambarkan situasi yang harus direspon dengan respon tertutup. Situasi yang diberikan pada partisipan diolah dari hasil yang didapatkan dari studi pertama, yaitu peneliti membuat dua jenis situasi dari 8 perilaku yang dinilai jahat dan 6 perilaku yang dinilai baik. Masing-masing perilaku kemudian diberi 12 alasan baik dan 12 alasan jahat berdasarkan hasil penelitian pada studi pertama. 
Gambaran situasi dibagi dua sesuai dengan dua kelompok yang akan dibandingkan dalam penelitian ini. Kelompok situasi pertama terdiri dari gambaran situasi dengan 6 perilaku baik yang masing-masing dilakukan dengan 12 alasan baik dan 8 perilaku jahat yang masing-masing dilakukan dengan 12 alasan jahat. Sedangkan pada kelompok situasi kedua, diberikan gambaran situasi dengan 6 perilaku baik yang masing-masing dilakukan dengan 12 alasan jahat dan 8 perilaku jahat yang masing-masing dilakukan dengan alasan baik.

Gambaran situasi tersebut disampaikan kepada partisipan kemudian mereka diminta untuk menentukan apakah perilaku yang dinyatakan dalam situasi adalah: sangat baik sekali (SBS), baik sekali (BS), baik (B), jahat (J), sangat jahat (SJ), atau sangat jahat sekali (SJS). Namun apabila partisipan berpikir bahwa situasi terlalu aneh, tidak masuk akal, atau tidak mungkin terjadi maka partisipan diminta untuk memilih tidak tahu (TT). Berdasarkan reaksi yang diberikan partisipan pada kertas jawaban, peneliti kemudian melakukan tabulasi untuk melihat sebaran jawaban partisipan dari gambaran situasi yang disampaikan.

Teknik Pengumpulan Data.Pengumpulan data dilakukan menggunakan kuisioner yang berikan pada partisipan berbentuk skala Likert dengan 7 (tujuh) tingkat respon. Adapun respon yang harus dipilih partisipan ketika menilai situasi bergerak dari "Sangat Baik Sekali" (SBS) hingga "Sangat Jahat Sekali" (SJS). Penggunaan kata "Jahat" untuk menekankan bahwa perilaku tersebut melanggar moral dan tidak sekadar "Buruk" atau "Jelek" yang belum tentu melanggar moral.

\title{
Teknik Analisis
}

Setelah didapatkan sebaran data reaksi partisipan terhadap tiap pernyataan, data kemudian dianalisis dengan membandingkan sebaran reaksi tiap situasi pada masing-masing kelompok. Perbandingan dilakukan pada perilaku yang sama namun dengan alasan yang berbeda, yaitu jahat dan baik. Secara khusus perbandingan dilakukan pada tiap alasan dari perilaku, namun secara umum perbandingan dilakukan pada kelompok perilaku dengan alasan yang bertolak belakang (perilaku jahat dengan alasan baik dan perilaku baik dengan alasan jahat).

Berdasarkan perbandingan tersebut dapat dilihat manakah yang lebih dominan antara kebaikan dan kejahatan. Apabila perilaku jahat yang dilakukan dengan alasan baik dan perilaku baik yang dilakukan dengan alasan jahat dinilai baik maka kebaikan lebih dominan daripada kejahatan. Sebaliknya apabila perilaku baik yang dilakukan dengan alasan jahat dan perilaku jahat yang dilakukan dengan alasan baik dinilai jahat maka kejahatan lebih dominan daripada kebaikan.

\begin{abstract}
ANALISIS \& HASIL
Analisis terhadap data yang didapatkan dari partisipan, didapatkan sebaran hasil yang cukup menarik. Pada perilaku baik yang dilakukan dengan alasan baik, didapatkan hasil sebagian besar partisipan $(91,4 \%)$ menilai perilaku tersebut baik dan hanya 1,4\% partisipan dari total partisipan dalam kelompok ini menilai perilaku tersebut jahat dan sebesar 7,3\% menjawab tidak tahu. Begitu juga pada perilaku jahat yang dilakukan dengan alasan jahat, $96,5 \%$ menilai jahat dan $0.003 \%$ perilaku tersebut dinilai baik, dan $0.03 \%$ menjawab tidak tahu.
\end{abstract}




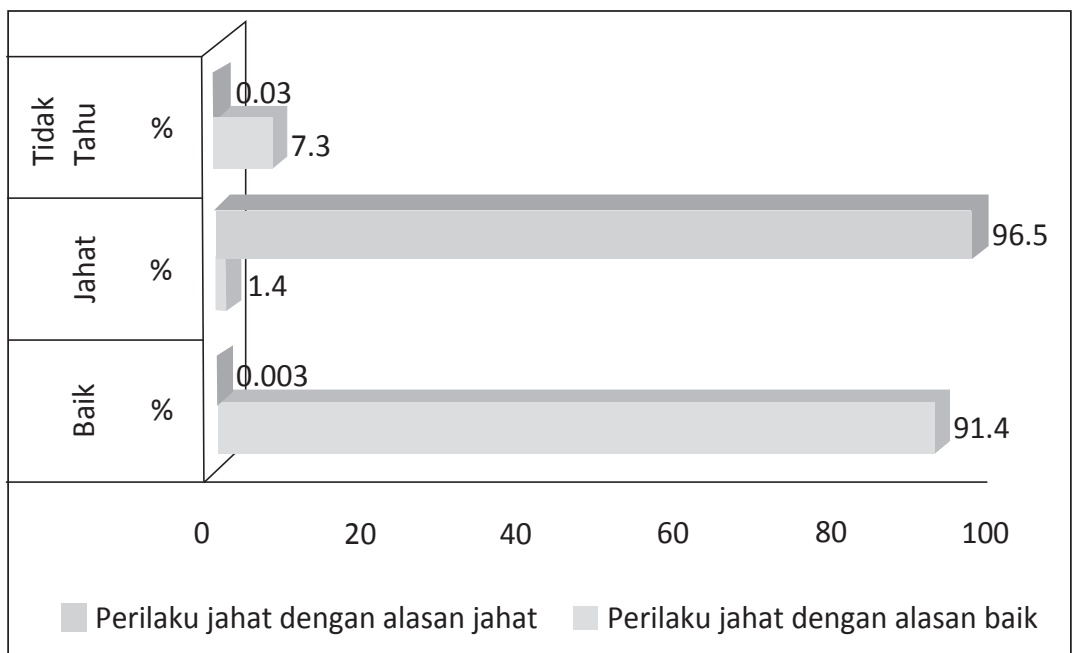

Bagan 1. Distribusi Persentase Perilaku dan Alasan yang Sejalan

Hasil di atas menunjukkan bahwa perilaku maupun alasan yang dijadikan acuan untuk penilaian "baik" atau "buruk"-nya moral sesuai dengan penilaian umum yang berlaku. Hasil ini juga menjadi dasar bahwa proses eksperimen dapat dilanjutkan pada tahap perlakuan di mana alasan baik dijadikan dasar untuk perilaku jahat dan alasan jahat dijadikan dasar untuk perilaku baik. Tahap ini dapat dikategorikan sebagai tahap pra-eksperimen di mana peneliti menguji apakah perilaku dan alasan yang sudah disampaikan oleh peneliti dapat digunakan dalam eksperimen.

Hasil pada kelompok di atas, sebagian besar (rata-rata 93.95\%) partisipan menilai sesuai dengan jenisnya, yaitu perilaku baik dengan alasan baik dinilai baik dan perilaku jahat dengan alasan jahat juga dinilai jahat. Ketidaksesuaian pernyataan yang disampaikan hanya disampaikan oleh sebagian kecil responden, $0.7 \%$, dan 3.65\% menilai tidak tahu atau tidak dapat memberi penilaian dengan berbagai alasan. Dengan mengacu pada ketidaksesuaian penilaian, yaitu perilaku baik dengan alasan baik dinilai jahat dan perilaku jahat dengan alasan jahat dinilai baik, sebesar 0.7\%, maka dapat ditarik kesimpulan bahwa lebih dari 99\% partisipan menilai sesuai yang diharapkan (dengan asumsi partisipan yang menilai tidak tahu akan menilai sesuai apabila partisipan familiar dengan pernyataan yang disampaikan).

Secara lebih rinci, distribusi persentase penilaian responden terhadap masing-masing perilaku dapat dilihat tabel 3 , yaitu seluruh perilaku baik yang dilakukan dengan alasan baik, memiliki pola yang sama dengan distribusi total. Hanya sedikit ada perbedaan pada perilaku sedekah di mana sekitar $5 \%$ perilaku sedekah yang dilakukan dengan alasan baik dinilai jahat. Pada perilaku yang lain, perilaku baik yang dilakukan dengan alasan baik hanya dinilai kurang dari $2 \%$ sebagai perilaku jahat dalam berbagai gradasinya yang sejalan dengan rata-rata umum.

Tabel 2. Rincian Distribusi Persentase Perilaku Baik Dengan dan Alasan Baik

\begin{tabular}{lccccccc}
\hline \multicolumn{1}{c}{ Perilaku } & SBS & BS & B & TT & J & JS & SJS \\
\hline Menolong & $27.01 \%$ & $21.84 \%$ & $41.38 \%$ & $9.48 \%$ & $0.29 \%$ & $0.00 \%$ & $0.00 \%$ \\
Sedekah & $22.13 \%$ & $17.09 \%$ & $41.74 \%$ & $13.45 \%$ & $4.48 \%$ & $0.84 \%$ & $0.28 \%$ \\
Jujur & $32.05 \%$ & $31.75 \%$ & $30.86 \%$ & $5.04 \%$ & $0.30 \%$ & $0.00 \%$ & $0.00 \%$ \\
Sabar & $32.14 \%$ & $28.87 \%$ & $35.71 \%$ & $3.27 \%$ & $0.00 \%$ & $0.00 \%$ & $0.00 \%$ \\
Hormat pada Orangtua & $34.03 \%$ & $20.90 \%$ & $36.42 \%$ & $7.16 \%$ & $0.90 \%$ & $0.00 \%$ & $0.60 \%$ \\
Sopan & $29.65 \%$ & $27.33 \%$ & $38.37 \%$ & $4.07 \%$ & $0.29 \%$ & $0.29 \%$ & $0.00 \%$ \\
\hline Rata-rata & $29.50 \%$ & $24.63 \%$ & $37.41 \%$ & $7.08 \%$ & $1.04 \%$ & $0.19 \%$ & $0.15 \%$ \\
\hline
\end{tabular}


Sedangkan pada perilaku jahat yang dilakukan dengan alasan jahat, masing-masing perilaku memiliki distribusi yang hampir sama dengan rata-rata distribusi. Hanya sedikit perbedaan pada perilaku korupsi di mana penilaian baik terhadap perilaku korupsi dengan alasan jahat juga dinilai baik oleh sekitar $2 \%$. Selebihnya tiap perilaku tergambar dalam rata-rata total dari delapan perilaku jahat yang diminta untuk dinilai.

Tabel 3. Rincian Distribusi Persentase Perilaku Jahat Dengan dan Alasan Jahat

\begin{tabular}{lllllllc}
\hline \multicolumn{1}{c}{ Perilaku } & SBS & BS & B & TT & J & JS & SJS \\
\hline Membunuh & $0.00 \%$ & $0.00 \%$ & $0.00 \%$ & $2.60 \%$ & $14.74 \%$ & $28.90 \%$ & $53.76 \%$ \\
Korupsi & $0.30 \%$ & $0.30 \%$ & $1.19 \%$ & $5.65 \%$ & $13.99 \%$ & $25.00 \%$ & $53.57 \%$ \\
Mencuri & $0.00 \%$ & $0.00 \%$ & $0.28 \%$ & $2.21 \%$ & $29.28 \%$ & $32.87 \%$ & $35.36 \%$ \\
Bohong & $0.00 \%$ & $0.00 \%$ & $0.00 \%$ & $2.49 \%$ & $29.28 \%$ & $32.87 \%$ & $35.36 \%$ \\
Berkhianat & $0.00 \%$ & $0.00 \%$ & $0.00 \%$ & $2.52 \%$ & $24.09 \%$ & $38.94 \%$ & $34.45 \%$ \\
Pemerkosaan & $0.00 \%$ & $0.00 \%$ & $0.00 \%$ & $2.08 \%$ & $10.09 \%$ & $28.78 \%$ & $59.05 \%$ \\
Fitnah & $0.00 \%$ & $0.00 \%$ & $0.00 \%$ & $3.87 \%$ & $20.54 \%$ & $34.23 \%$ & $41.37 \%$ \\
Mengolok-olok & $0.00 \%$ & $0.00 \%$ & $0.00 \%$ & $4.62 \%$ & $27.46 \%$ & $38.44 \%$ & $29.48 \%$ \\
\hline Rata-rata & $0.00 \%$ & $0.00 \%$ & $0.05 \%$ & $2.96 \%$ & $23.46 \%$ & $34.36 \%$ & $39.18 \%$ \\
\hline
\end{tabular}

Berdasarkan hasil eksperimen yang sudah dilakukan didapatkan data sebagai berikut: perilaku baik yang dilakukan dengan alasan jahat hanya dinilai 7.7\% sebagai perilaku baik, 86.7\% dinilai jahat, dan 5.6\% tidak menilai (tidak tahu). Sebaliknya pada perilaku jahat yang dilakukan dengan alasan yang baik didapatkan hasil yang tidak jauh berbeda dengan perilaku jahat yang dilakukan dengan alasan baik. Adapun sebaran data yang terjadi pada penilaian perilaku jahat dengan alasan baik adalah sebagai berikut: $86 \%$ penilaian adalah jahat, $7.4 \%$ baik, dan $6.6 \%$ tidak menilai (tidak tahu).

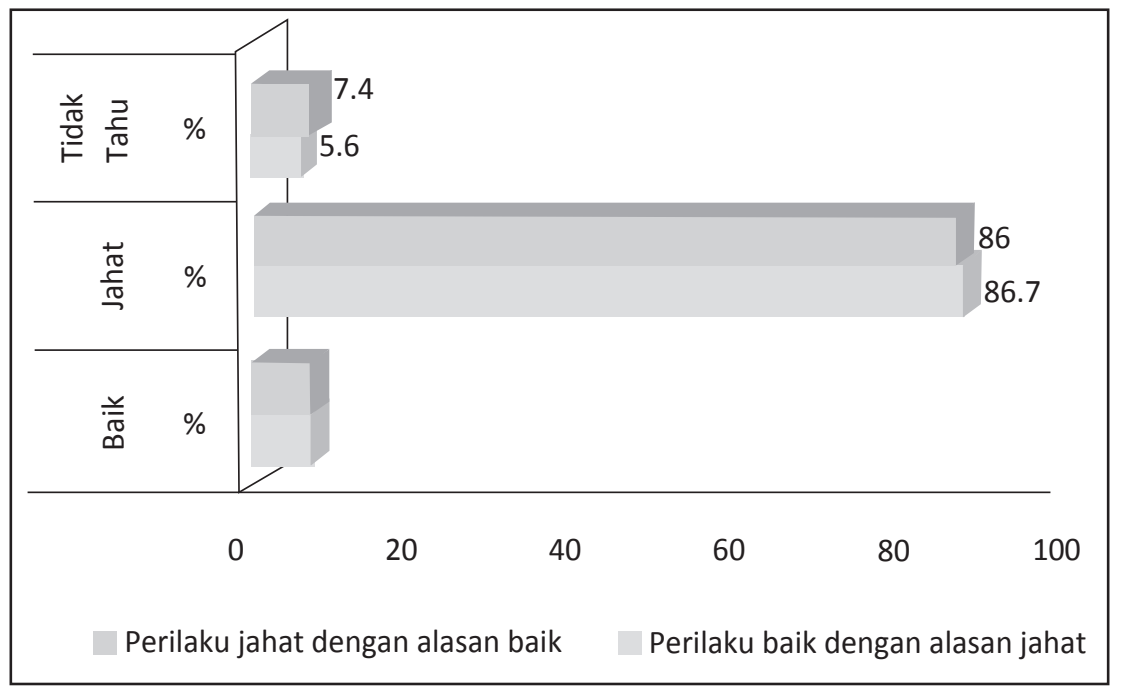

Bagan 2. Distribusi Persentase Perilaku dan Alasan yang Tidak Sejalan

Berdasarkan hasil analisis yang didapatkan dari proses eksperimen, didapatkan hasil yang menunjukkan bahwa perilaku baik yang dilakukan dengan alasan jahat akan dinilai jahat dan perilaku jahat yang dilakukan 
dengan alasan baik akan dinilai jahat juga. Adapun perbedaan penilaian antara perilaku baik yang dilakukan dengan alasan jahat dan perilaku jahat dengan alasan baik, berdasarkan data yang didapatkan, hampir tidak ada beda antara kedua kelompok. Perbedaan kedua kelompok, berdasarkan data yang diperoleh, tidak mencapai $1 \%$ antar kelompok.

Berdasarkan hasil di atas, di mana tidak ada beda antara penilaian baik dengan alasan jahat dan penilaian jahat dengan alasan baik maka hasil tersebut dinilai hampir sama walaupun penjelasannya akan menunjukkan perbedaan yang signifikan. Kedua kelompok perilaku tersebut rata-rata 7.6\% dinilai baik, 86.3\% dinilai jahat, dan $6.5 \%$ tidak dapat menilai. Jika menggunakan asumsi yang sama dengan dua kelompok perilaku sebelumnya, yaitu tidak familiar dengan pernyataan, maka lebih dari $92 \%$ penilaian terhadap kedua kelompok perilaku adalah jahat.

Secara rinci, perilaku baik yang dilakukan dengan alasan jahat memiliki pola yang serupa dengan rata-rata distribusi keseluruhan perilaku tersebut. Adapun perilaku yang sedikit lebih tinggi dari rata-rata keseluruhan perilaku adalah perilaku menolong, sedekah, dan jujur, yaitu sekitar $10 \%$ tetap menilai perilaku tersebut baik walaupun dilakukan dengan alasan jahat. Pada sisa perilaku lainnya, yaitu sabar, hormat pada orangtua, dan sopan umumnya hampir sama dengan rata-rata penilaian keseluruhan.

Tabel 4. Rincian Distribusi Persentase Perilaku Baik Dengan dan Alasan Jahat

\begin{tabular}{lccccccc}
\hline \multicolumn{1}{c}{ Perilaku } & SBS & BS & B & TT & J & JS & SJS \\
\hline Menolong & $5.14 \%$ & $0.40 \%$ & $5.53 \%$ & $0.79 \%$ & $5.14 \%$ & $26.09 \%$ & $56.92 \%$ \\
Sedekah & $4.15 \%$ & $0.64 \%$ & $3.19 \%$ & $4.15 \%$ & $24.92 \%$ & $25.88 \%$ & $37.06 \%$ \\
Jujur & $1.92 \%$ & $3.21 \%$ & $6.73 \%$ & $9.94 \%$ & $29.81 \%$ & $23.40 \%$ & $25.00 \%$ \\
Sabar & $2.56 \%$ & $0.96 \%$ & $1.92 \%$ & $2.88 \%$ & $32.27 \%$ & $27.48 \%$ & $31.95 \%$ \\
Hormat pada Orangtua & $1.60 \%$ & $1.28 \%$ & $1.92 \%$ & $8.31 \%$ & $27.80 \%$ & $31.31 \%$ & $27.80 \%$ \\
Sopan & $1.22 \%$ & $1.52 \%$ & $3.05 \%$ & $6.71 \%$ & $26.83 \%$ & $29.57 \%$ & $31.10 \%$ \\
\hline Rata-rata & $2.76 \%$ & $1.33 \%$ & $3.72 \%$ & $5.46 \%$ & $24.46 \%$ & $27.29 \%$ & $34.97 \%$ \\
\hline
\end{tabular}

Seperti sebelumnya, perilaku jahat yang dilakukan degan alasan baik juga memiliki distribusi yang kurang lebih sama. Pada distribusi ini yang menarik adalah perilaku berbohong dengan alasan baik yang juga dinilai baik oleh sekitar 35\% partisipan. Namun sebaran frekuensi perilaku lainnya, hampir sama dengan rata-rata penilaian yang diberikan pada perilaku jahat yang dilakukan dengan alasan baik.

Tabel 5. Rincian Distribusi Persentase Perilaku Jahat Dengan dan Alasan Baik

\begin{tabular}{lccrrccc}
\hline \multicolumn{1}{c}{ Perilaku } & SBS & BS & \multicolumn{1}{c}{ B } & \multicolumn{1}{c}{ TT } & J & JS & SJS \\
\hline Membunuh & $0.00 \%$ & $0.44 \%$ & $1.33 \%$ & $1.77 \%$ & $18.14 \%$ & $38.94 \%$ & $39.38 \%$ \\
Korupsi & $0.00 \%$ & $1.54 \%$ & $1.85 \%$ & $6.77 \%$ & $21.54 \%$ & $19.69 \%$ & $48.62 \%$ \\
Mencuri & $0.32 \%$ & $1.94 \%$ & $5.18 \%$ & $11.33 \%$ & $29.45 \%$ & $26.54 \%$ & $25.24 \%$ \\
Bohong & $2.23 \%$ & $2.55 \%$ & $30.89 \%$ & $9.55 \%$ & $28.98 \%$ & $12.42 \%$ & $13.38 \%$ \\
Berkhianat & $0.00 \%$ & $0.67 \%$ & $3.70 \%$ & $9.09 \%$ & $28.96 \%$ & $27.95 \%$ & $29.63 \%$ \\
Pemerkosaan & $0.00 \%$ & $0.00 \%$ & $0.32 \%$ & $3.21 \%$ & $12.50 \%$ & $19.87 \%$ & $64.10 \%$ \\
Fitnah & $1.00 \%$ & $0.00 \%$ & $3.34 \%$ & $3.34 \%$ & $38.46 \%$ & $22.41 \%$ & $31.44 \%$ \\
Mengolok-olok & $0.00 \%$ & $0.00 \%$ & $0.00 \%$ & $6.71 \%$ & $20.77 \%$ & $41.21 \%$ & $31.31 \%$ \\
\hline Rata-rata & $0.59 \%$ & $0.86 \%$ & $7.24 \%$ & $7.21 \%$ & $26.52 \%$ & $25.07 \%$ & $32.52 \%$ \\
\hline
\end{tabular}


Hasil studi 2 ini menunjukkan bahwa perilaku jahat yang dilakukan dengan alasan baik akan dinilai sama dengan perilaku baik yang dilakukan dengan alasan jahat. Kedua kelompok perilaku tersebut, oleh partisipan, dinilai sebagai perilaku yang jahat. Berdasarkan fakta ini, dapat disimpulkan bahwa kejahatan lebih dominan daripada kebaikan dan adanya unsur kejahatan akan mengubah perilaku atau alasan baik menjadi jahat.

\section{DISKUSI}

Hasil studi 1 menunjukkan betapa sulitnya untuk membuat batasan antara kebaikan dan kejahatan. Adapun pelabelan perilaku jahat umumnya lebih sekadar menyesuaikan dengan pelabelan yang memang sudah umum dilakukan oleh masyarakat. Membunuh, contohnya, walaupun dalam kondisi tertentu dapat dibenarkan (misalnya: polisi membunuh penjahat yang melarikan diri) namun konotasi negatif yang sudah melekat pada perilaku tersebut menyebabkan sebagian besar masyarakat akan mengatakan bahwa membunuh adalah perilaku yang jahat.

Menurut Dauenhauer (2007) kesulitan dalam menentukan apakah sebuah perilaku dapat dikategorikan baik atau jahat karena batasan kejahatan sangat sulit untuk ditegakkan. Kesulitan itu karena tidak pernah ada konsep yang dapat diterima secara umum dan dapat berlaku secara luas. Contohnya perang yang diyakini oleh sebagian besar manusia sebagai "jalan yang salah," namun dengan alasan tertentu dapat dinilai sebagai sesuatu yang baik dan bermartabat.

Hal yang hampir sama terjadi pada pelabelan baik. Individu cenderung akan lebih mengarahkan pada konsep-konsep normatif yang bersifat abstrak dalam menentukan perilaku yang baik, seperti: sabar dan menolong. Konsep-konsep tersebut sebenarnya tidak memiliki cukup argumentasi untuk dianggap sebagai sebuah perilaku karena terlalu luas dan abstrak.

Kesulitan dalam menentukan batas jahat tentunya berimplikasi pada sulitnya membuat batasan baik. Namun untuk kebaikan, sedikit terjawab dalam studi 2 yang menunjukkan bahwa sesuatu hanya akan dinilai baik apabila perilaku dan alasan perilaku tersebut juga dinilai baik. Dengan demikian, pernyataan Dauenhauer (2007) mengenai sulitnya membuat batasan kejahatan karena kejahatan tidak hanya dapat terjadi sebagai akibat dorongan alasan jahat, namun juga ketika kebaikan dilakukan dengan alasan jahat atau alasan kebaikan dilakukan dengan cara yang jahat.

Hasil studi 2 yang menunjukkan bahwa kebaikan dan kejahatan apabila berinteraksi tetap akan dinilai jahat juga dapat menjelaskan pernyataan Dauenhauer (2007) mengenai sulitnya mengatasi kejahatan. Salah satu hal yang menjadikan masyarakat sulit mengatasi kejahatan adalah "adanya unsur kebaikan" dalam kejahatan tersebut, terutama ketika terjadi interaksi antara kebaikan dan kejahatan. Interaksi ini dapat terjadi dalam bentuk perilaku jahat dengan alasan baik atau perilaku baik dengan alasan jahat.

Silke (2004) dalam penelitiannya terhadap pelaku teroris menunjukkan sulitnya membuat klasifikasi kebaikan dan kejahatan ketika dua hal tersebut saling berinteraksi. Dalam penelitiannya, Silke merujuk pada pelaku teroris, sebagai perilaku yang paling banyak dikutuk saat ini, namun dinilai sangat berbeda oleh pelakunya yaitu sebagai pejuang atau tentara yang berani. Selain itu, Silke juga menguatkan konsepnya dengan penelitian yang menunjukkan bahwa pelaku teroris bahkan tidak dapat dikategorikan sakit jiwa jika melihat dasar nilai dan perilaku mereka.

Penelitian ini tidak hanya menjawab problematika konseptual, seperti yang diajukan Dauenhauer dan Silke serta peneliti lain yang membahas penilaian moral (Moral Judgment) namun juga dapat menjawab 
pertanyaan sosial mengenai sulitnya mencari "orang baik" dalam kehidupan sehari-hari. Jika mengacu pada penelitian ini, maka peluang menemukan orang baik hanya berkisar 1 dari empat orang, yaitu ketika perilaku bertemu dengan alasan yang baik. Namun demikian, pada prakteknya prinsip peluang tidak banyak berarti dalam menentukan baik atau jahat sebuah perilaku.

\section{SIMPULAN \& SARAN}

Berdasarkan penelitian ini, dapat disimpulkan bahwa persepsi seseorang terhadap baik dan jahat tidak mengikuti pola logika. Dalam persepsi penilaian terhadap baik dan jahat, perilaku atau alasan yang dinilai jahat akan lebih dominan dibandingkan perilaku dan alasan baik. Dengan demikian, untuk dapat mencapai perilaku yang dinilai baik, seseorang harus melakukan perilaku yang dinilai baik dengan alasan yang juga baik.

Sebaliknya jika perilaku baik dilakukan dengan alasan jahat atau perilaku jahat dilakukan dengan alasan baik maka persepsi manusia terhadap perilaku tersebut adalah jahat. Bahkan secara umum, jika perilaku baik atau jahat jika dilakukan dengan alasan sebaliknya akan dinilai relatif hampir sama. Jika dilihat sedikit lebih mendalam, perbedaan penilaian dari perilaku jahat dengan alasan jahat terhadap perilaku baik yang dilakukan dengan alasan jahat dan perilaku jahat yang dilakukan dengan alasan baik hanya terdapat sedikit perbedaan, yaitu sekitar $8 \%$.

Berdasarkan penelitian ini maka penilaian moral (moral judgement) terhadap sesuatu tidak dapat terjadi berdasarkan konsep yang dipahami secara umum, yaitu individu akan menilai perilaku secara objektif. Fakta penelitian ini memberi pemahaman yang lebih baik pada kita bahwa harapan bahwa manusia dapat memberi pertimbangan dan penilaian yang adil perlu ditinjau ulang. Namun demikian, sebagai manusia yang mampu belajar tentunya penelitian ini diharapkan dapat menjadi salah satu dasar untuk membuat sistem penilaian yang lebih adil pada banyak kondisi di sekitar manusia.

Berkaitan dengan pengembangan hasil penelitian ini, beberapa tema penelitian yang dapat dikembangkan antara lain melihat bias budaya dalam pengambilan keputusan dan jenis perilaku jahat dan baik. Pada penelitian ini, korupsi merupakan salah satu perilaku jahat yang banyak disebut partisipan penelitian, namun belum dapat dipastikan apakah disebutnya perilaku korupsi ini merupakan bagian dari norma yang berlaku umum atau hanya pada kasus Indonesia. Sedangkan pada aspek pengambilan keputusan, penelitian ini juga belum dapat mengungkap perbedaan penilaian moral pada individu yang memiliki keyakinan pada nilai moral bersifat absolut dan yang memiliki keyakinan nilai moral bersifat relatif.

\section{DAFTAR PUSTAKA}

Burns, Stuart A. (2008). Moral Judgment. http://www3.sympatico.ca/saburns/pg0402.htm (accessed: March $30,2011)$.

Dauenhauer, B.P. (2007). Responding to Evil. The Southern Journal of Philosophy. Memphis: Summer 2007. Vol. 45, Iss. 2; pg. 207-222. ProQuest document ID: 1297478521. Accessed: 16 Februari 2010.

Dien, D.S. (1997). Worldviews and Morality; How Do They Intersect?. Human Development. Basel: Nov/Dec 1997. Vol. 40, Iss. 6; pg. 345-349. ProQuest document ID: 25330572. Accessed: 24 Februari 2010. 
El Hafiz, S. (2003). Dinamika Moral pada Santri di Pondok Pesantren Darunnajah, Jakarta, Skripsi. Universitas Diponegoro. Tidak diterbitkan.

Haidth, J. dan S. Kesebir. (2010). Morality. In S. Fiske, D. Gilbert, \& G. Lindzey (eds.). Handbook of Social Psychology. $5^{\text {th }}$ edition. Hobeken NJ.: Wiley. Pg. 797-832.

Hare, R. D. (1993). Without Conscience. New York: Pocket Books.

Helmuth, L. (2001). Moral Reasoning Relies on Emotion. Science. Washington: Sep 14, 2001. Vol. 293, Iss. 5537; pg. 1971-1972. ProQuest document ID: 8197617. Accessed: 16 Februari 2010.

Krause, K.W. (2009). Prosocial Maintenance in The Age of Religious Decline, The Humanist. Washington, DC: Mar/Apr 2009. Vol. 69, Iss. 2; pg. 41-42. ProQuest document ID: 1652076431. Accessed: 19 Februari 2010.

Miller, J. G. (1997). Understanding of the Role of Worldview in Morality. Human Development. Basel: Nov/ Dec 1997. Vol. 40, Iss. 6; pg. 350-354. ProQuest document ID: 25330576. Accessed: 24 Februari 2010.

Nucci, L. (2002). Because It is The Right Thing to Do. Human Development. Basel: Mar/Apr 2002. Vol. 45, Iss. 2; pg. 125-129. ProQuest document ID: 117846907. Accessed: 24 Februari 2010.

Schwartz, E. (2004). Why Some Ask Why. Judaism. New York: Summer 2004. Vol. 53, Iss. 3/4; pg. 230240. ProQuest document ID: 924574411. Accessed: 24 Februari 2010.

Shaughnessy, J.J., E.B. Zechmeister, \& J.S. Zechmeister. (2007). Metodologi Penelitian Psikologi (Terj.: H.P. Soetjipto dan S.M. Soetjipto). Yogyakarta: Pustaka Pelajar.

Silke, A. (2004). Courage in Dark Places; Reflections on Terrorist Psychology. Social Research. New York: Spring 2004. Vol. 71, Iss. 1; pg. 177-198. ProQuest document ID: 635862181. Accessed: 24 Februari 2010.

Suharsono. (2000). Pengalaman-pengalaman Personal Malu dan Rasa Bersalah. Tesis. Jakarta: Fakultas Psikologi UI (tidak diterbitkan). 
